\title{
FABRICATION OF LARGE-AREA CCD DETECTORS ON HIGH-PURITY, FLOAT-ZONE SILICON*
}

J.A. Gregory, B.E. Burke, M.J. Cooper,

R.W. Mountain, and B.B. Kosicki

Lincoln Laboratory

Massachusetts Institute of Technology

Lexington, Massachusetts 02173-9108

*This work was sponsored, in part, by the Department of the Air Force and the National Aeronautics and Space Administration.

"Opinions, interpretations, conclusions, and recommendations are those of the author and are not necessarily endorsed by the United States Air Force." 


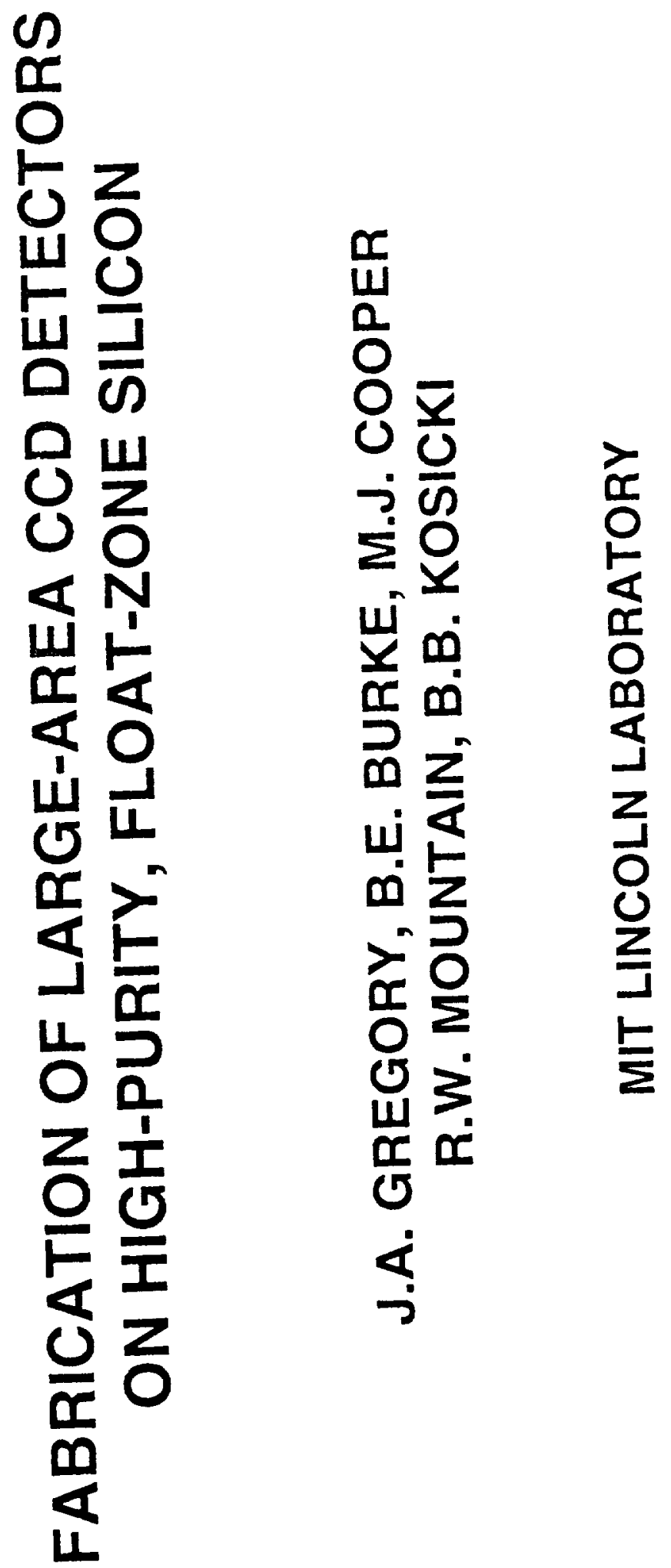




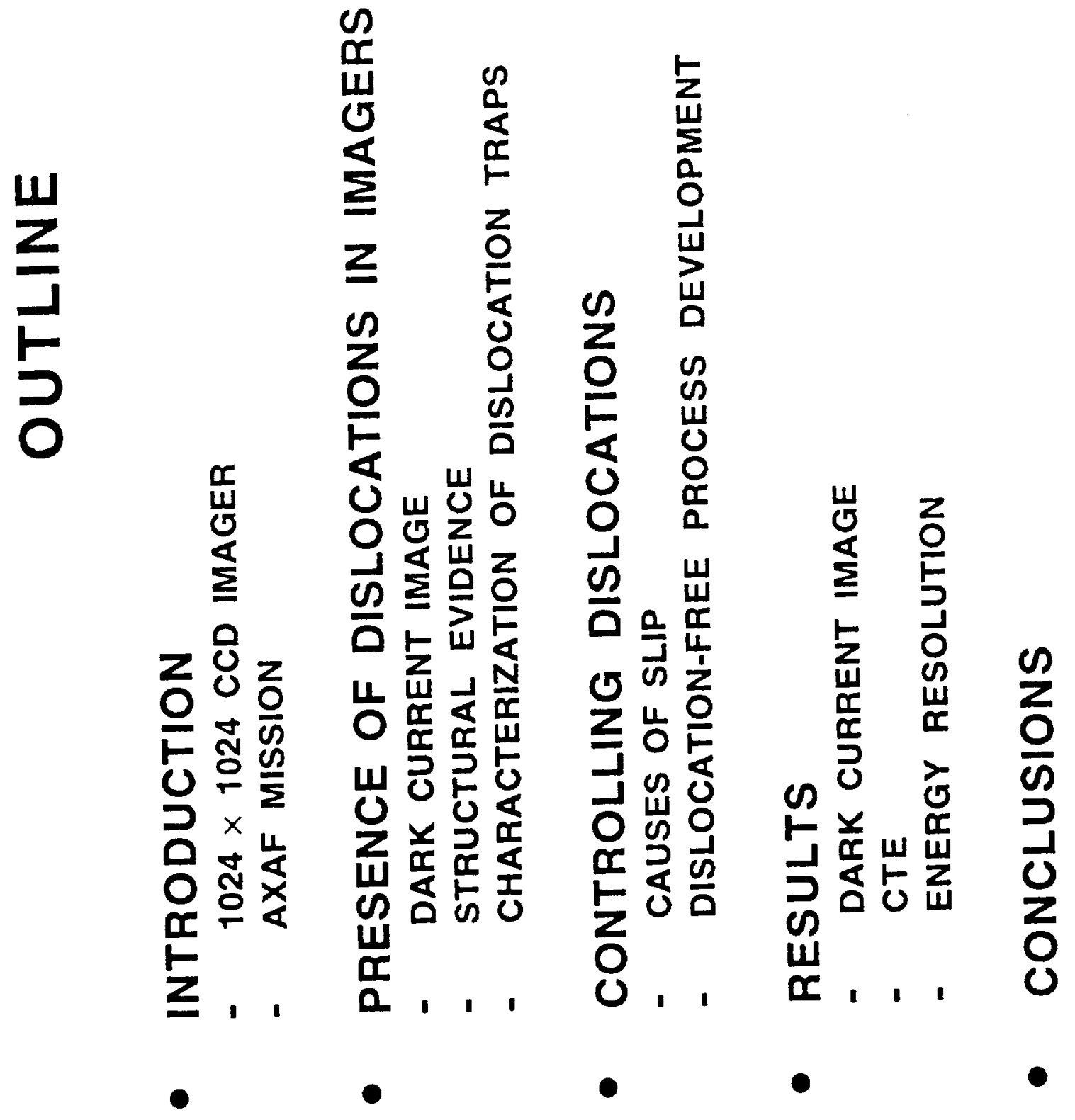




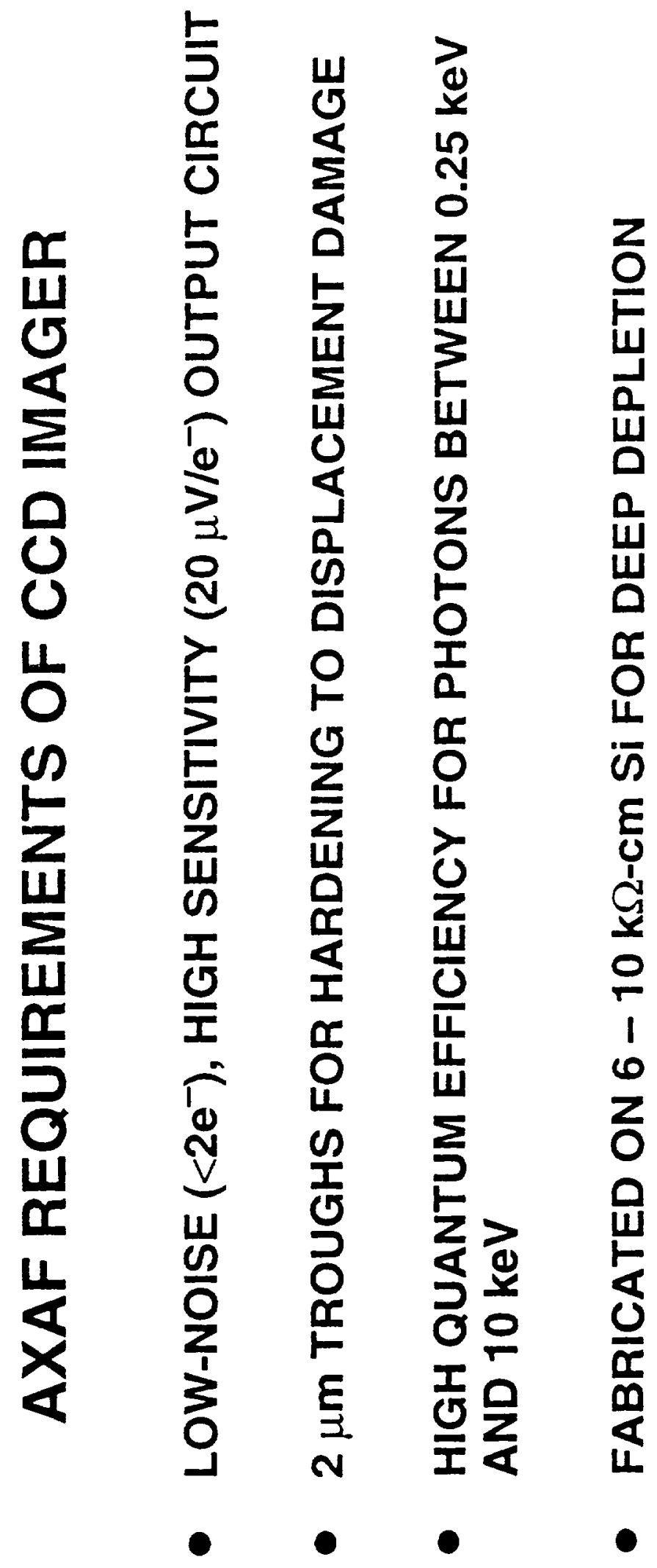




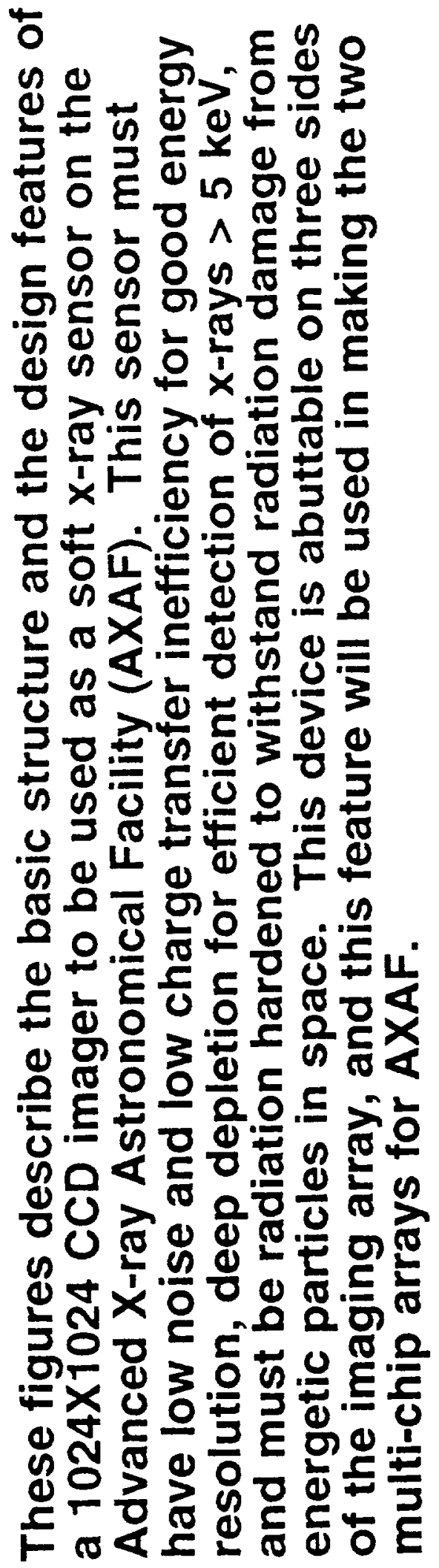




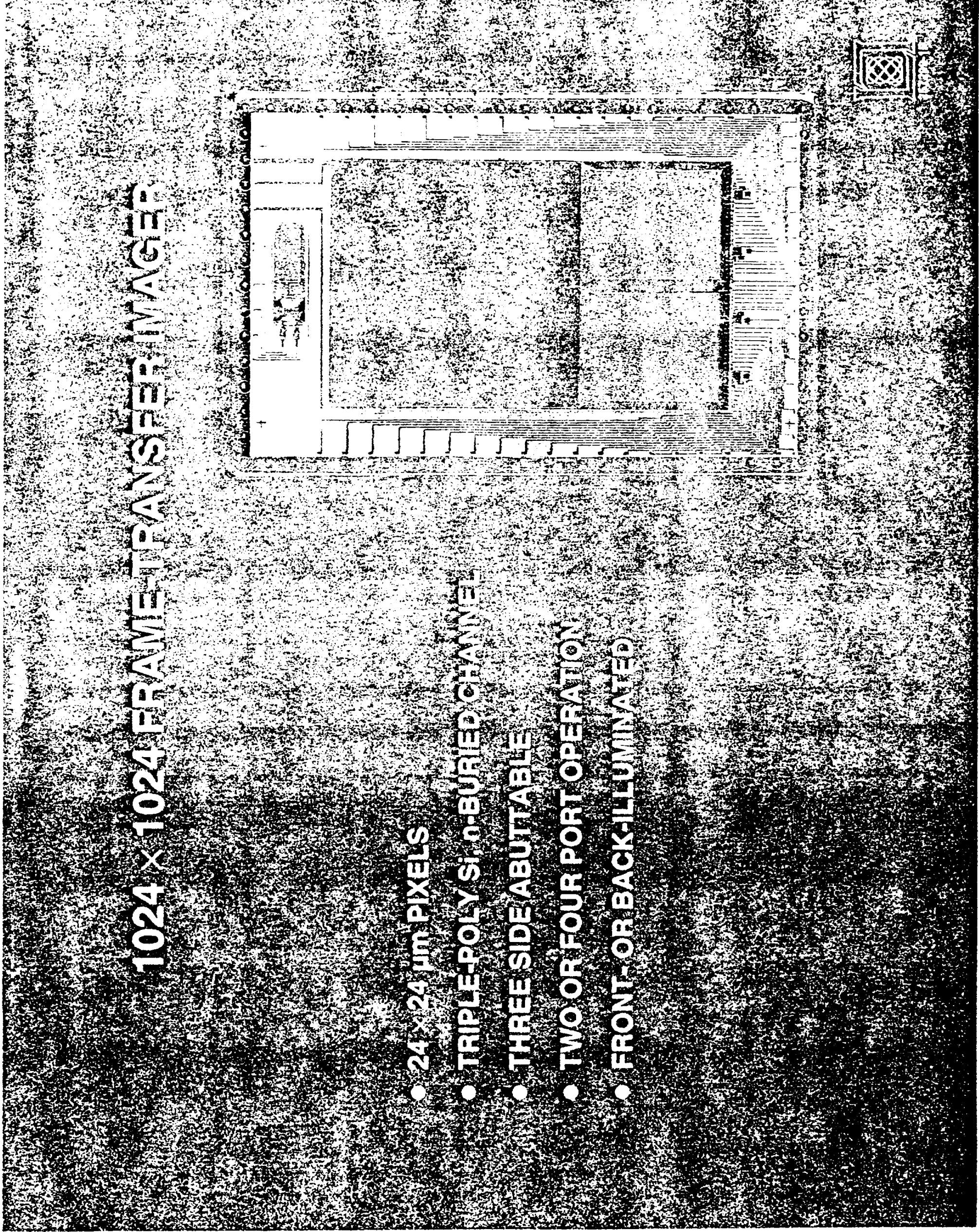




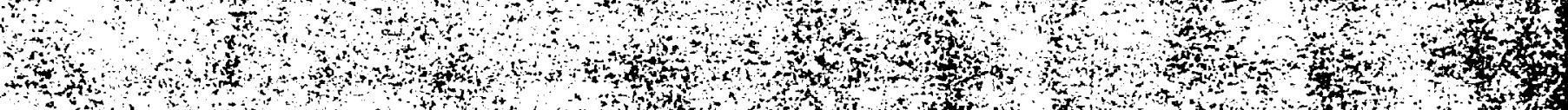

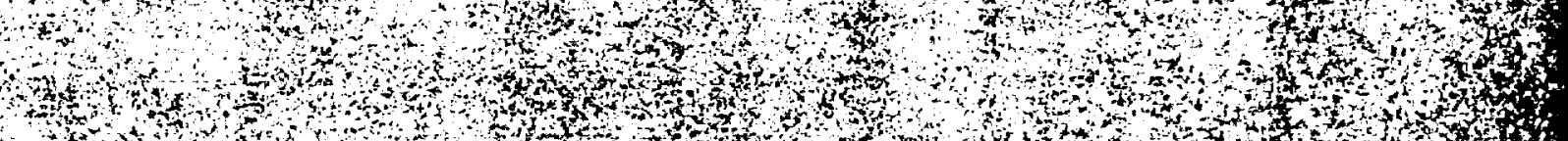

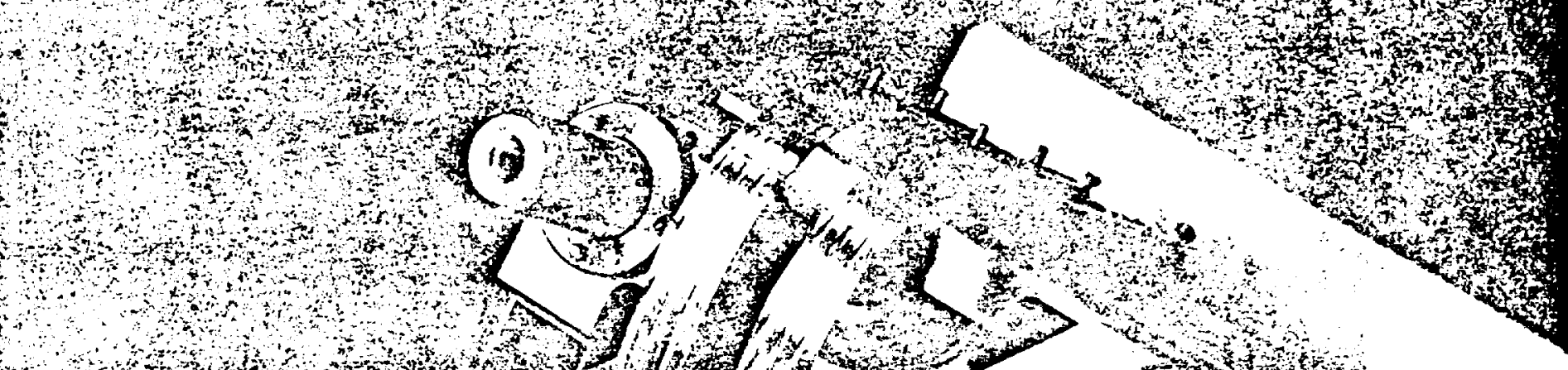

W. - 5.2.

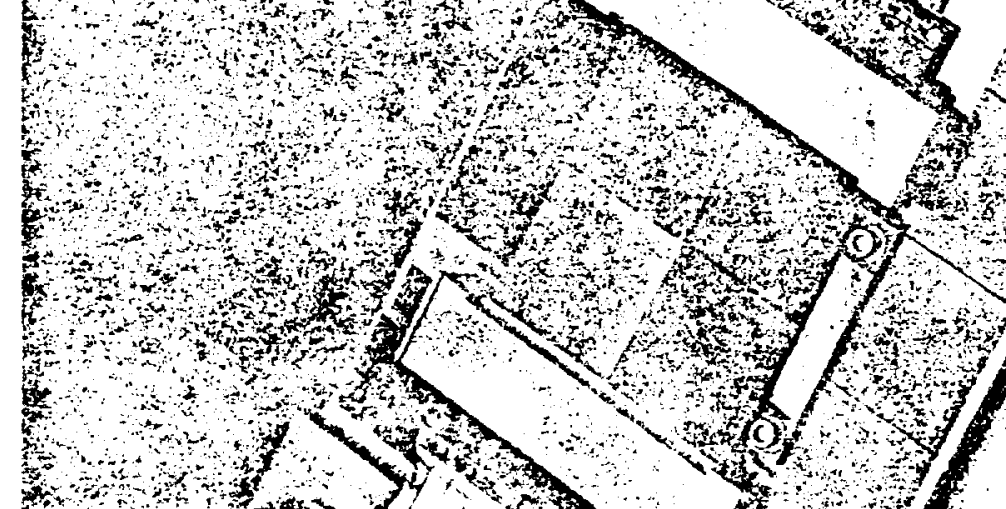

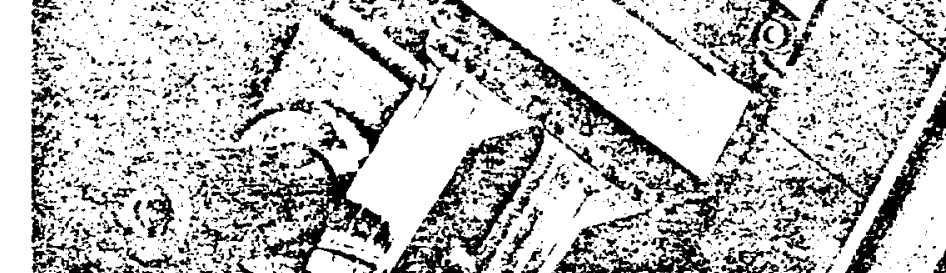
, (1) 2. (5) H,

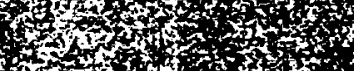

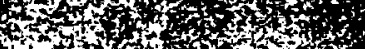

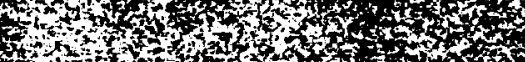

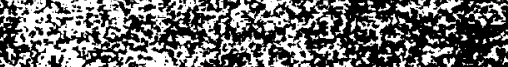

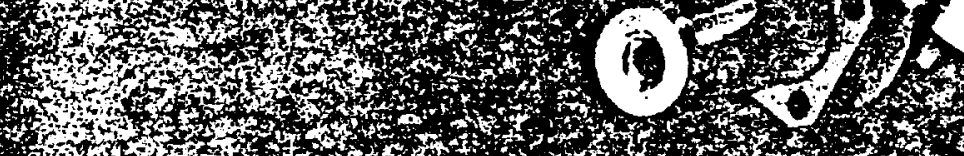

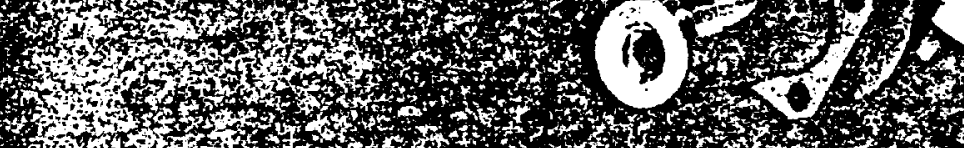
1.? 4. 1.t. (2.7.7. 17.6.: : 17.6: W

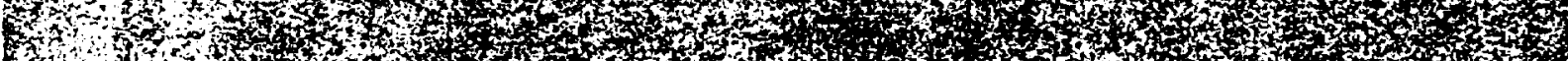
2. 1.7. 


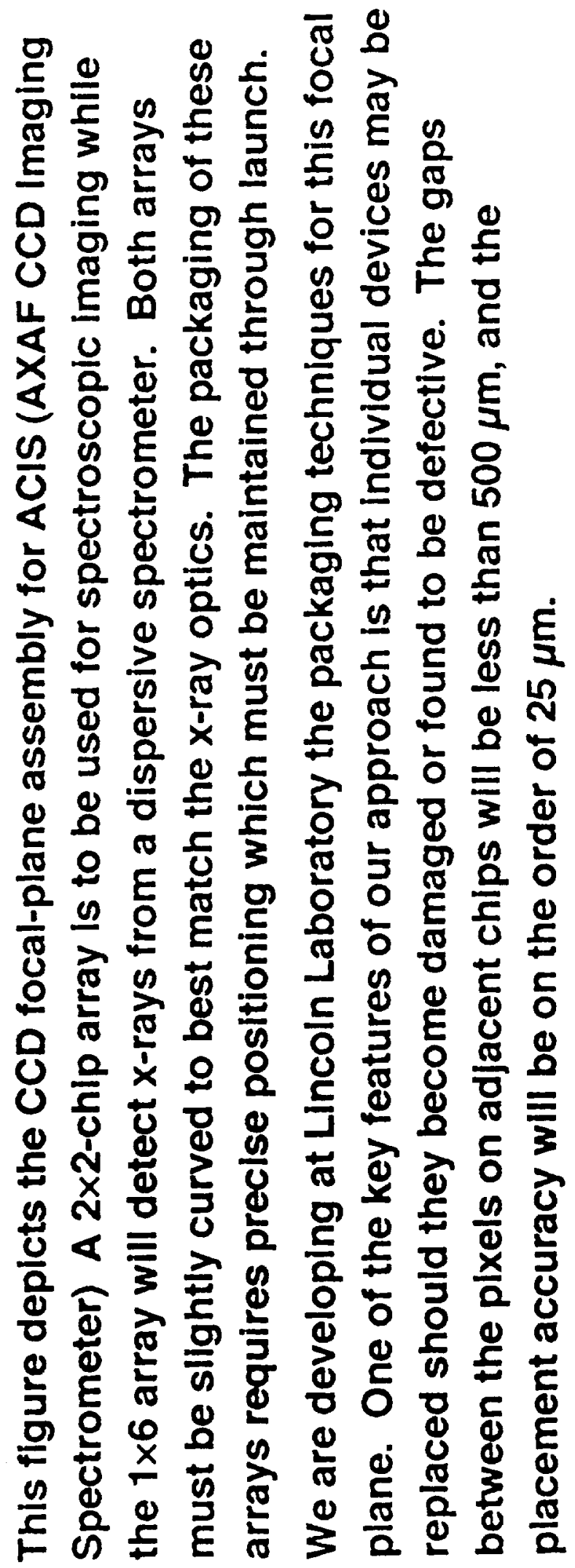




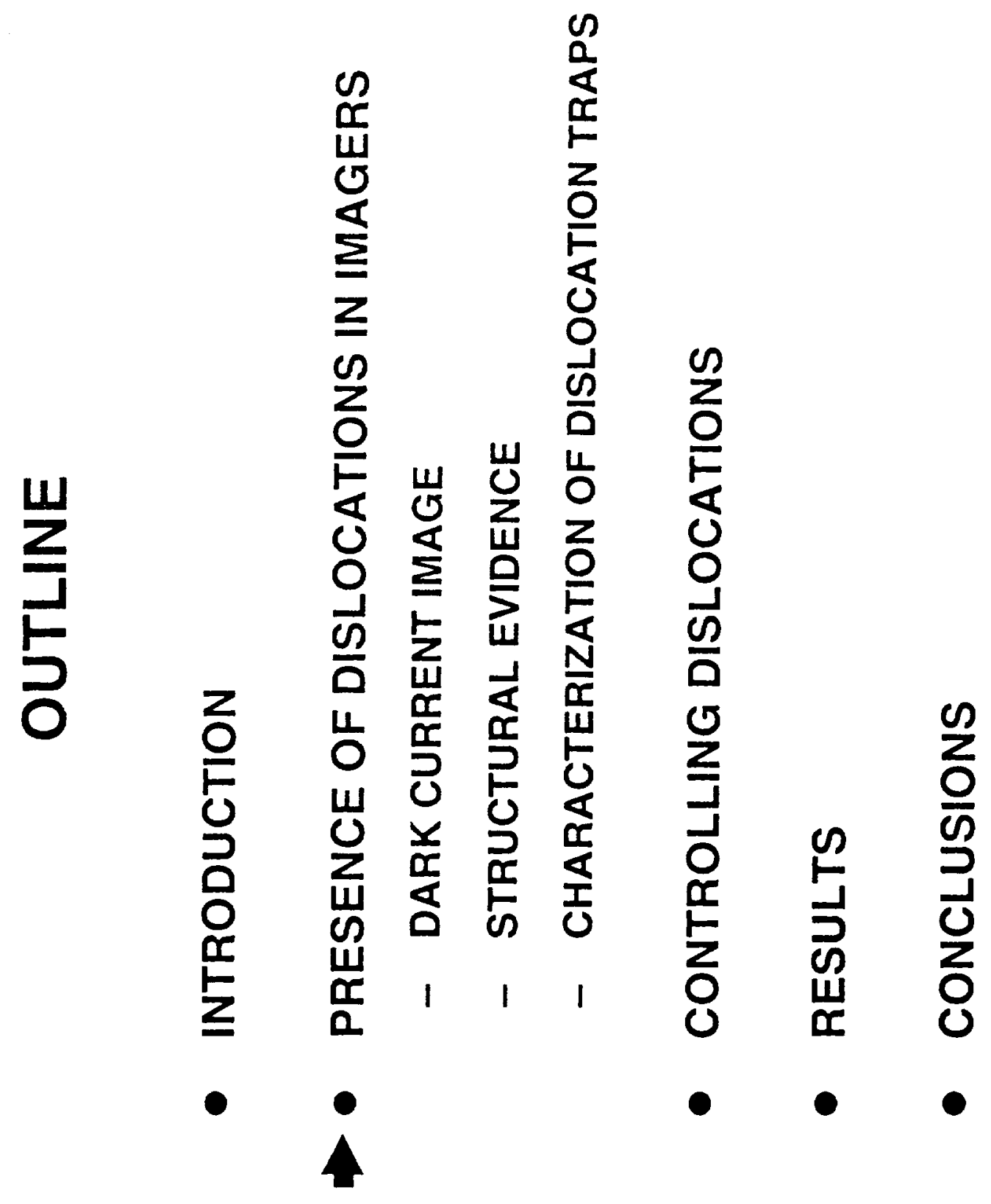




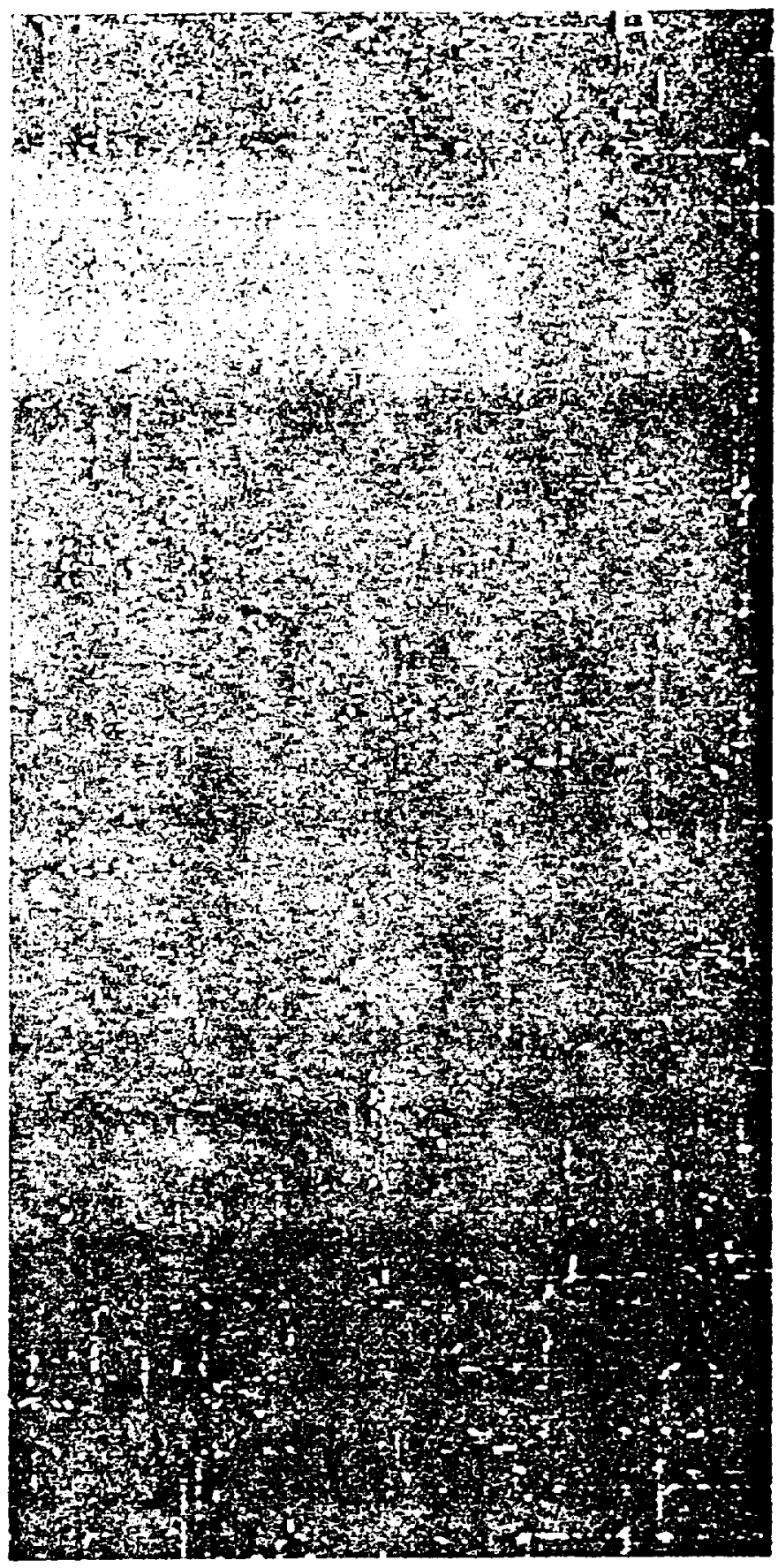




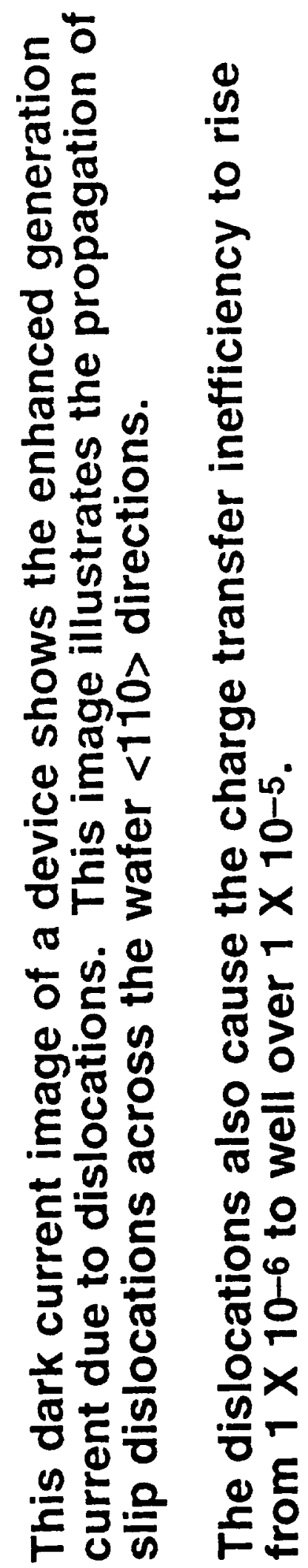




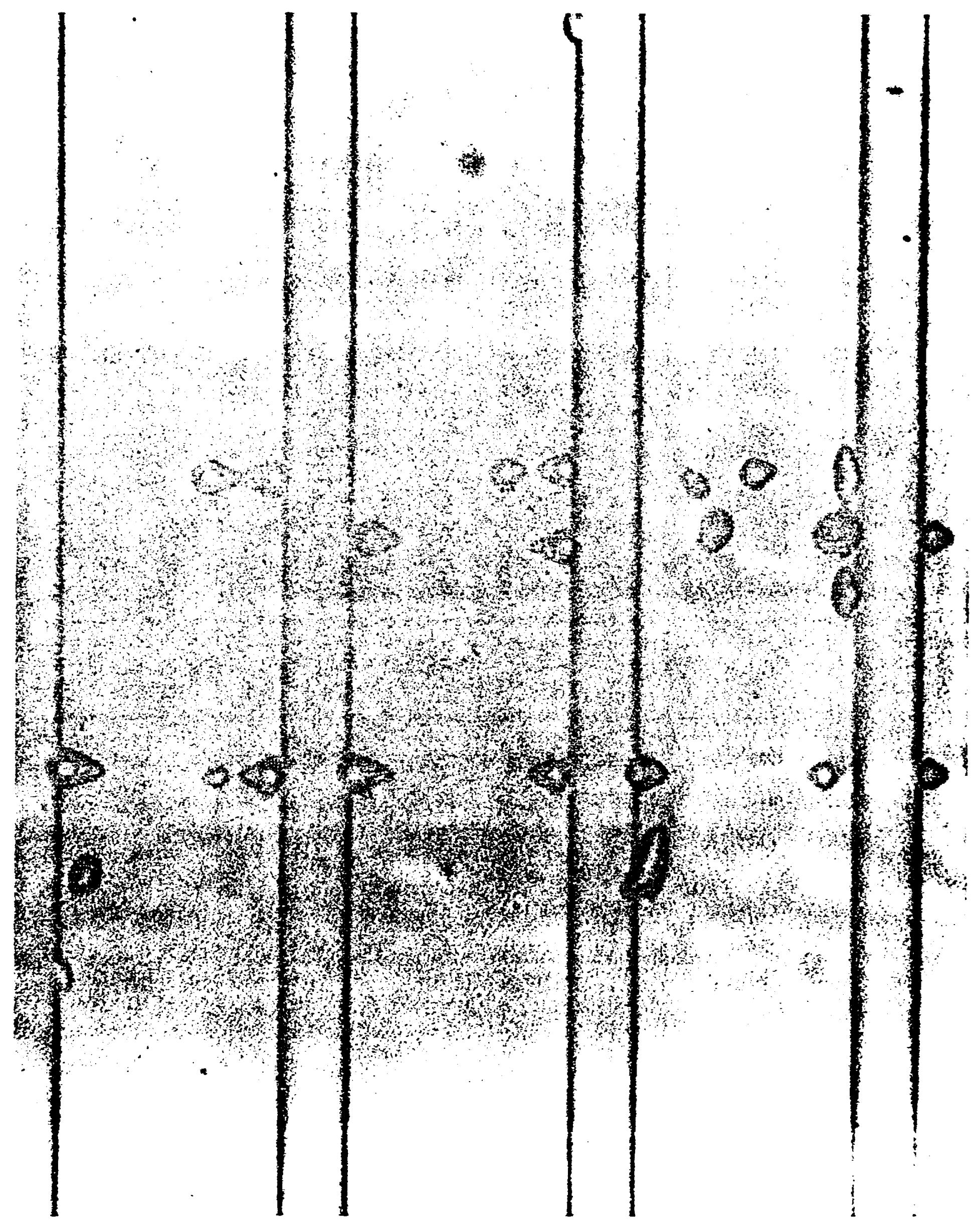




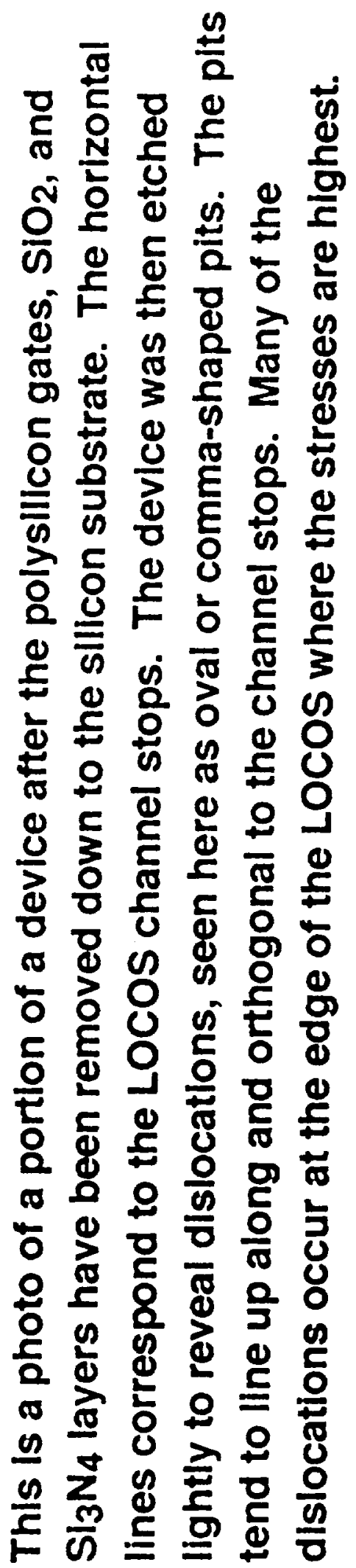




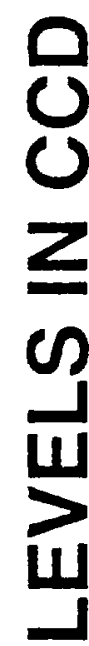

0

$\stackrel{5}{\square}$

岁<smiles>[3H]I</smiles>
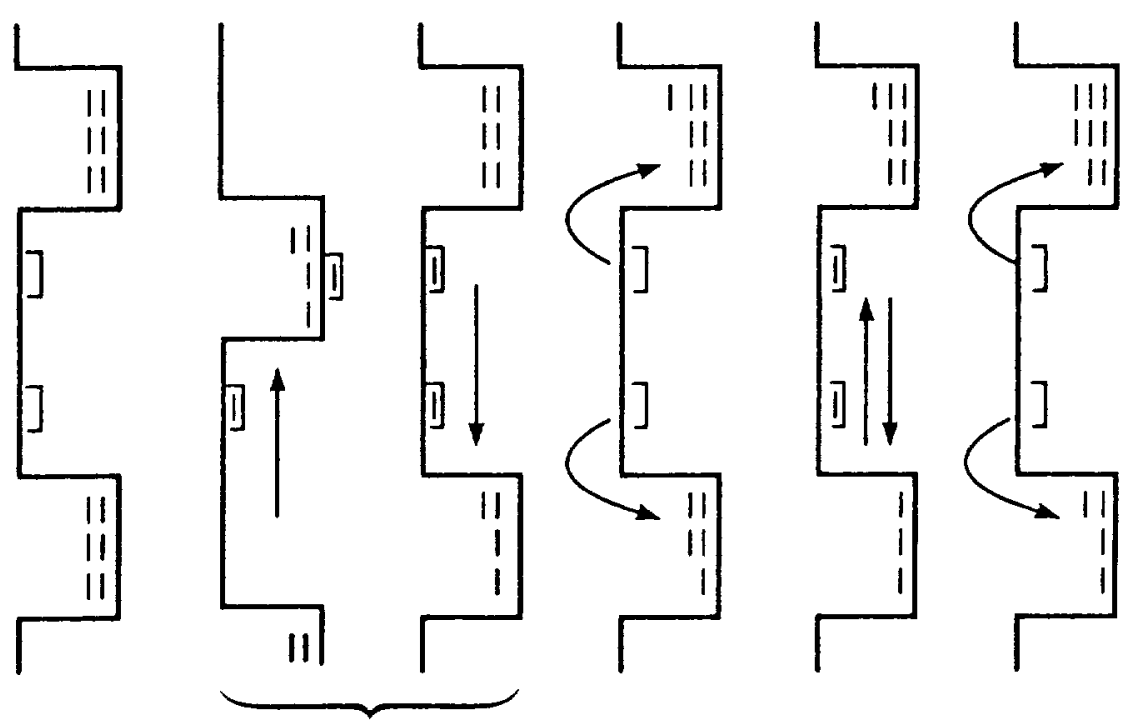

픔

드닝

寻亭

口

$>0$

西至

岳是

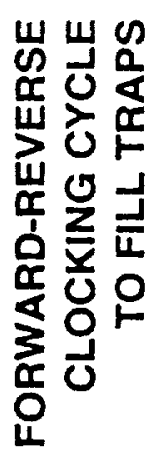

告

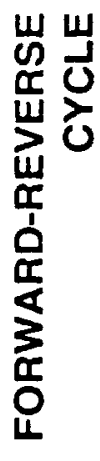

号衣 


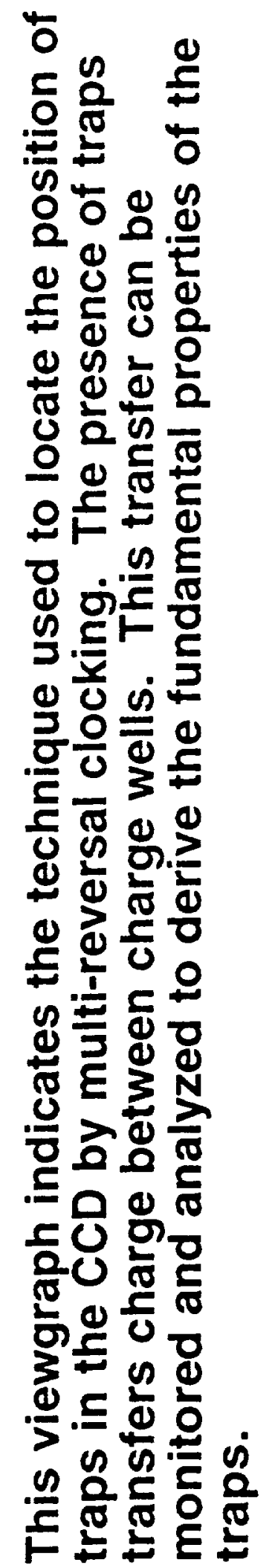



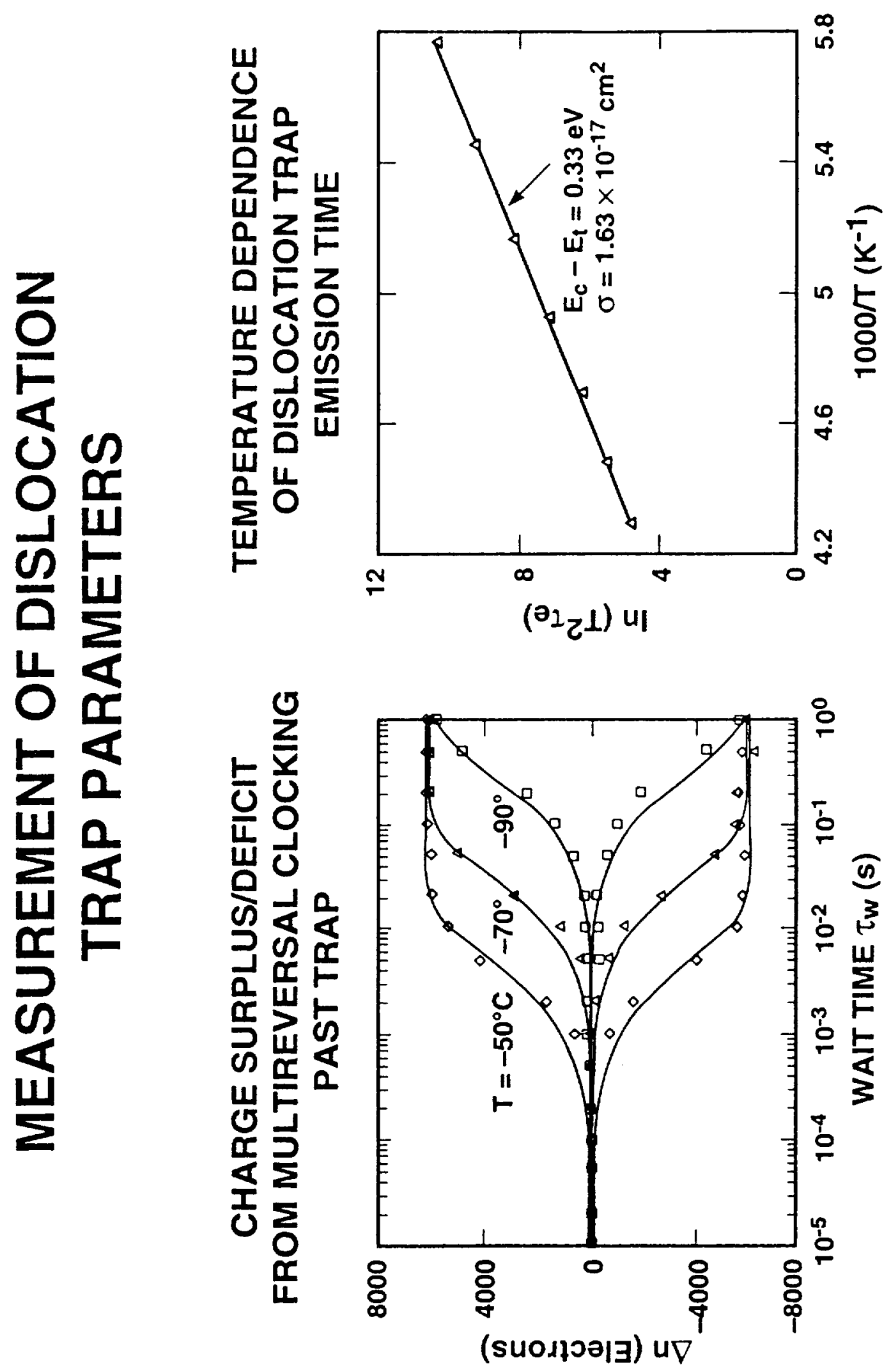


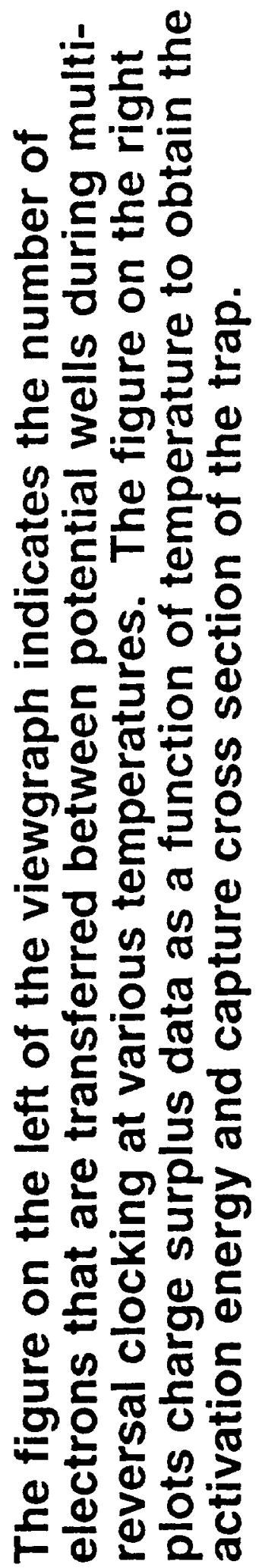



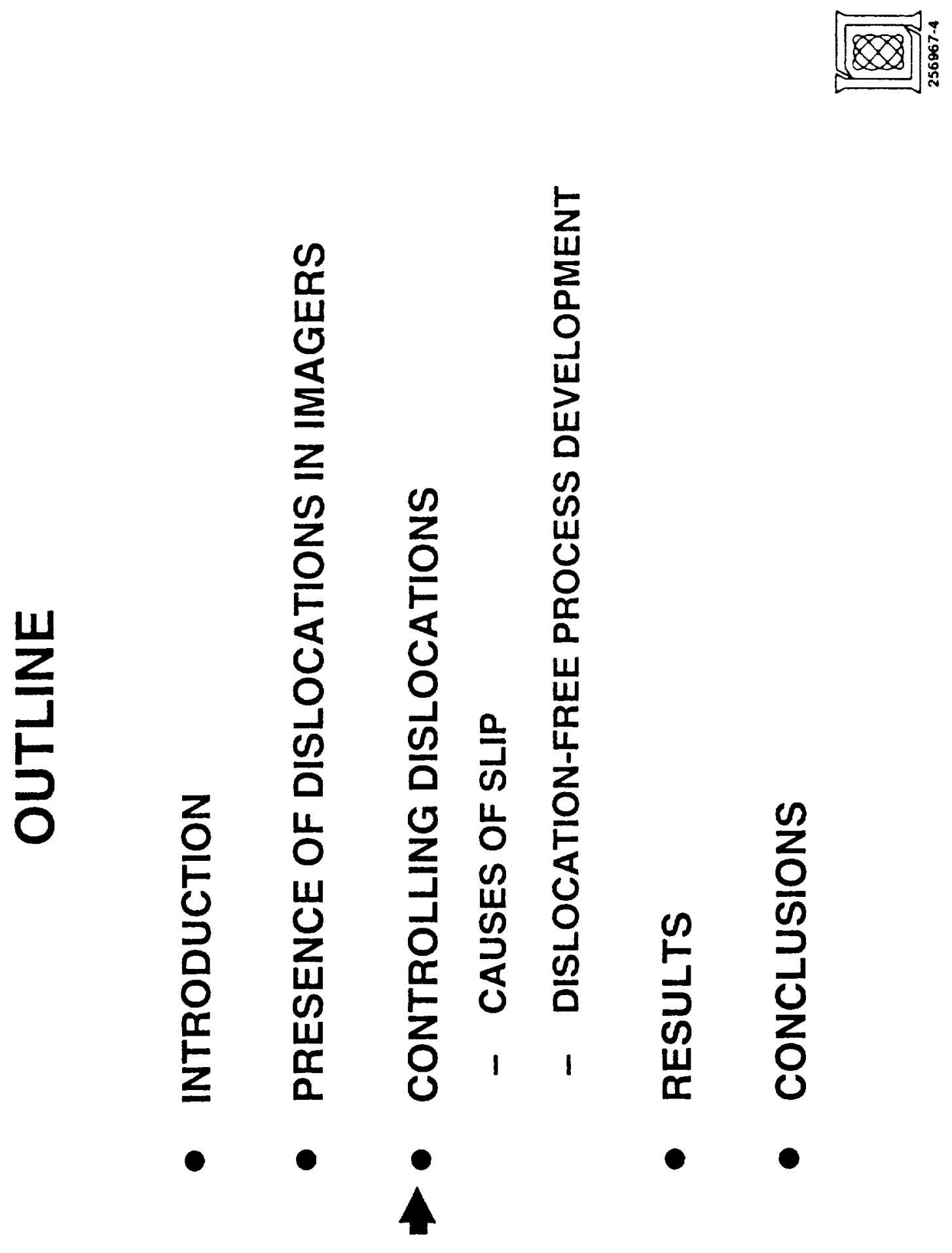


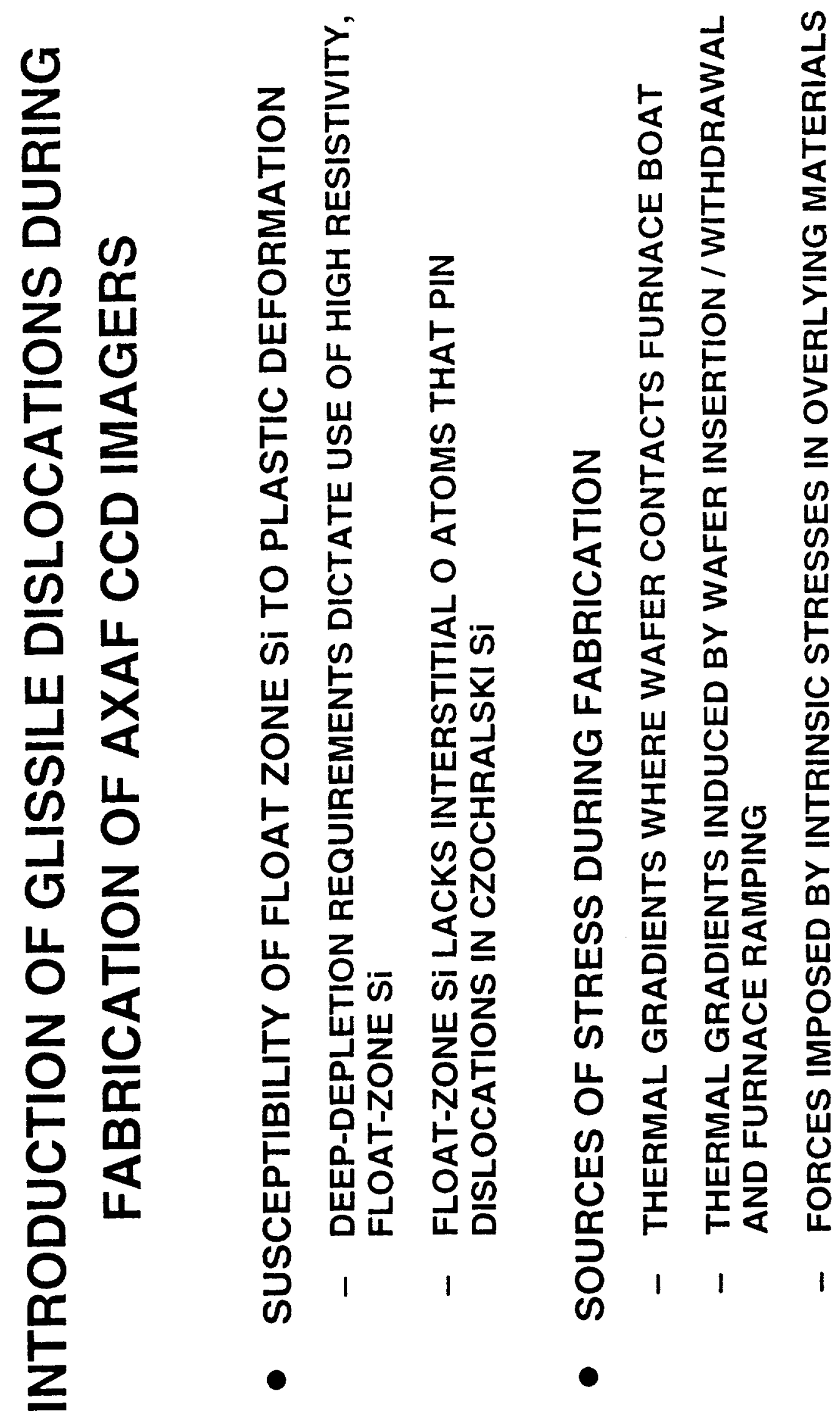




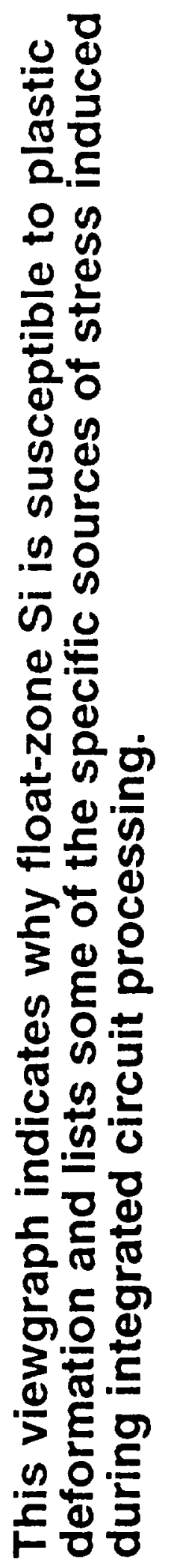




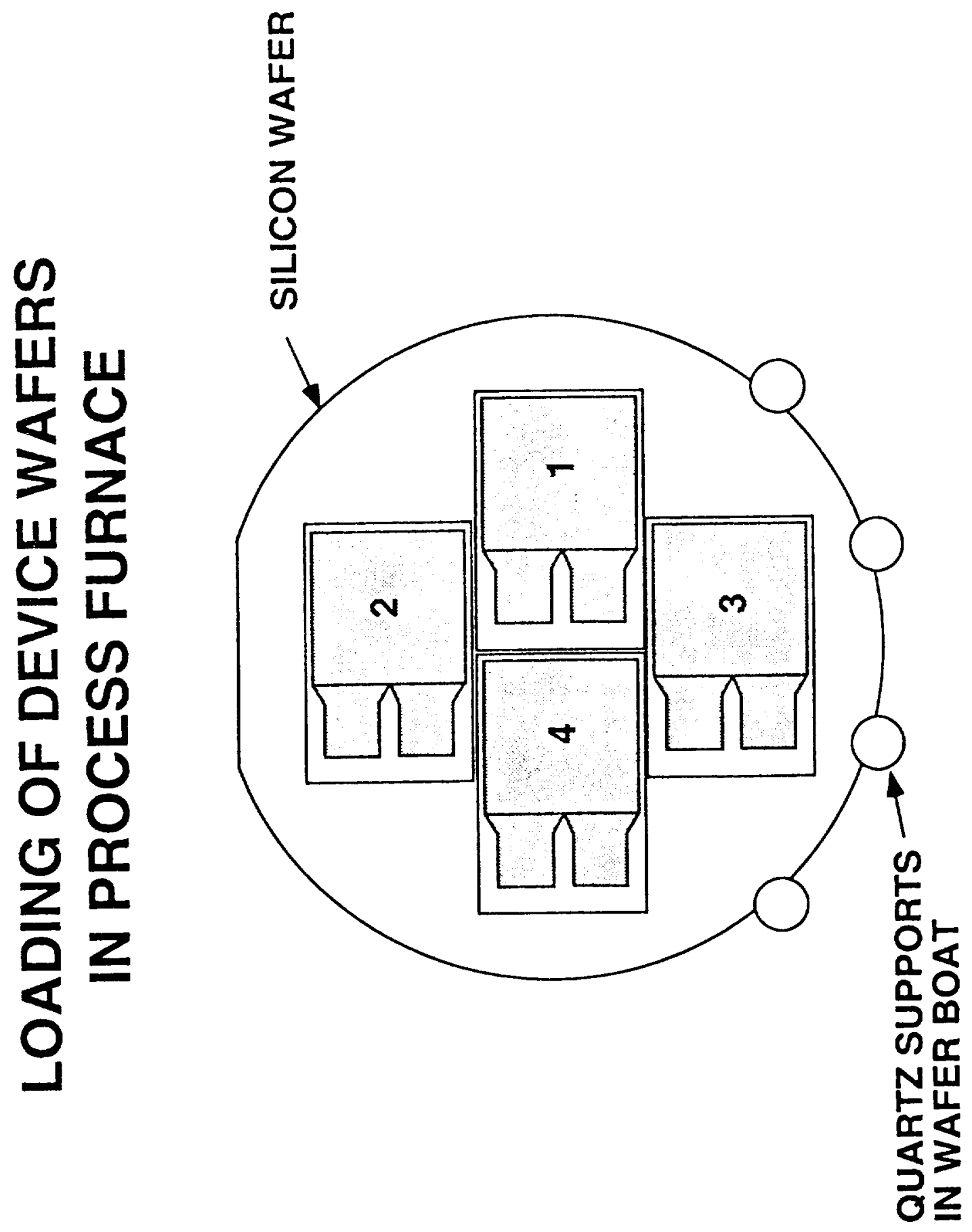




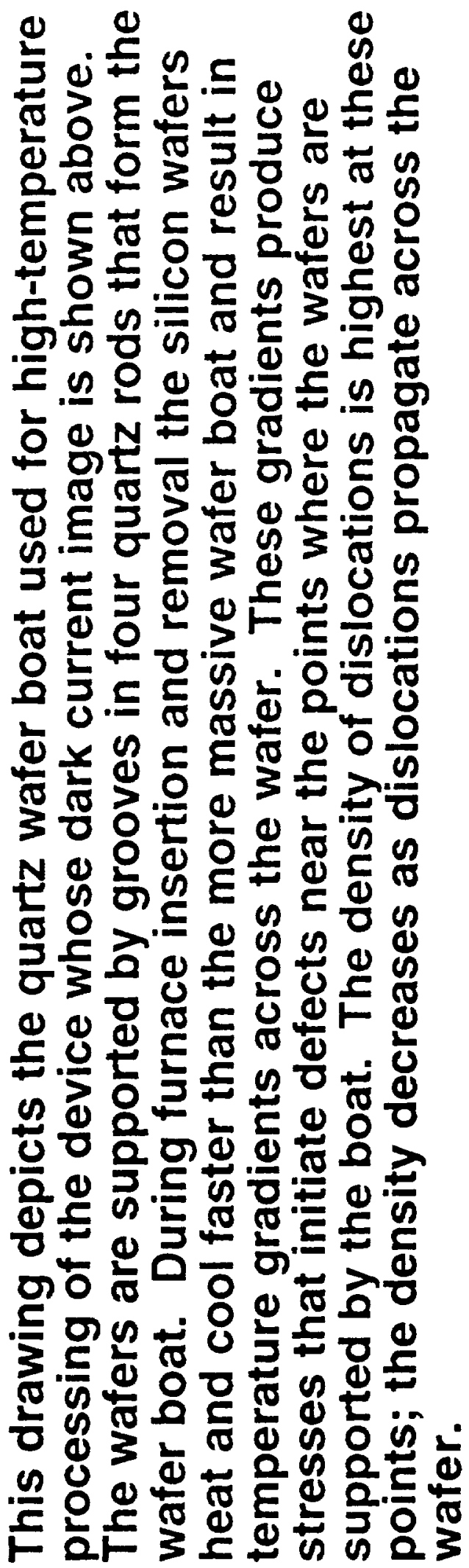




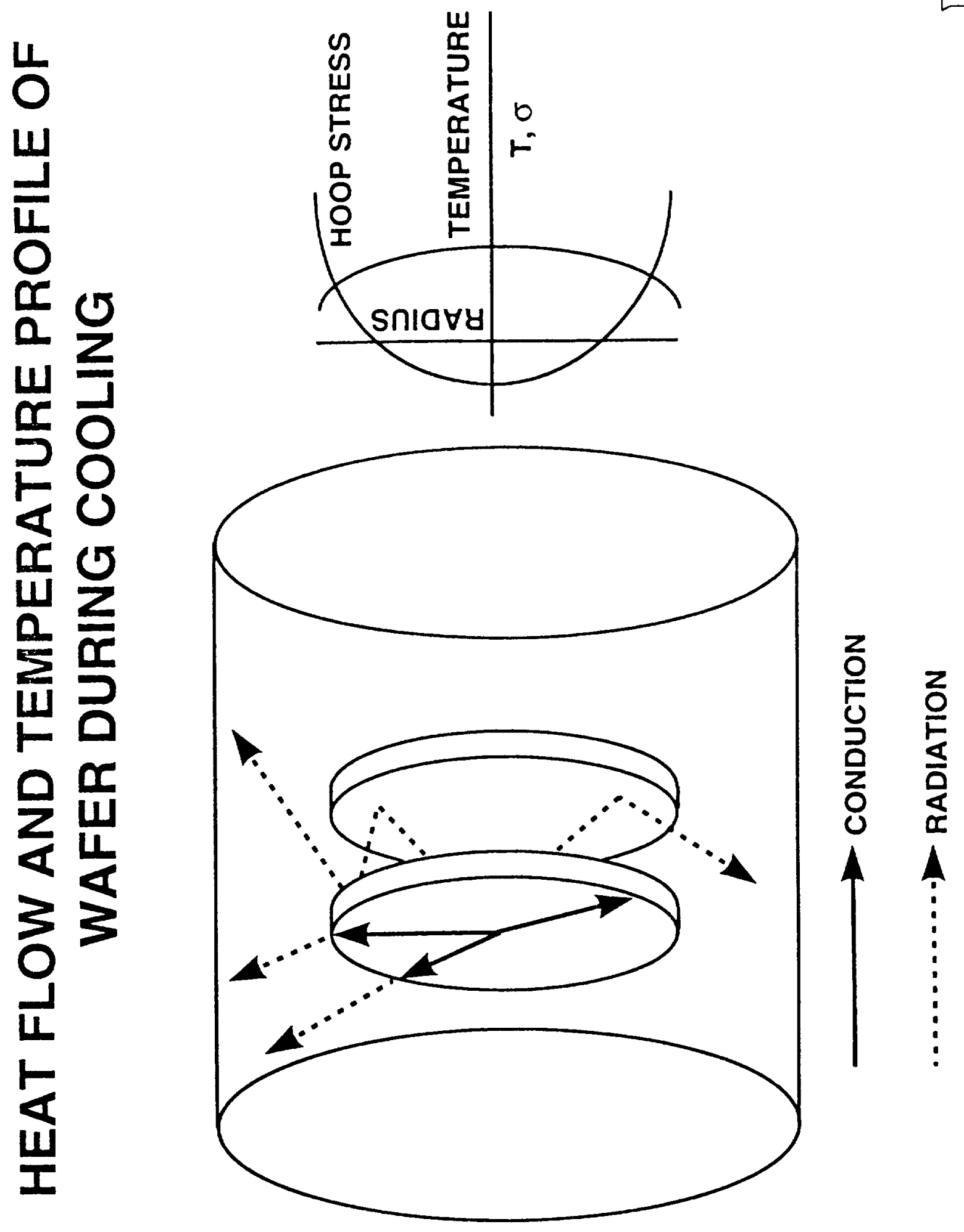




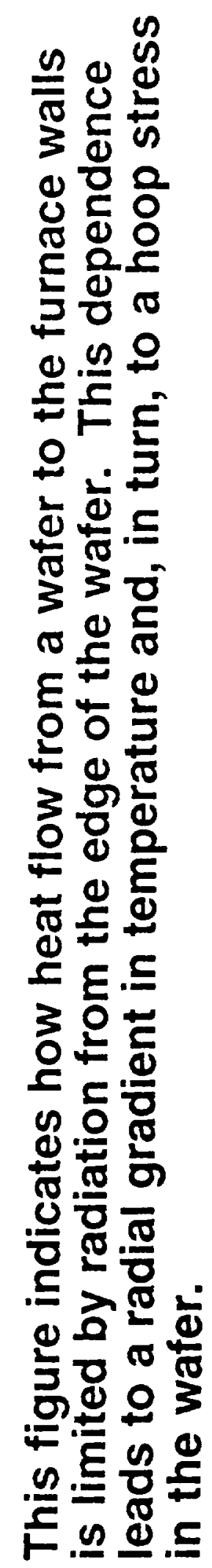


$\frac{\sum^{n}}{2}$

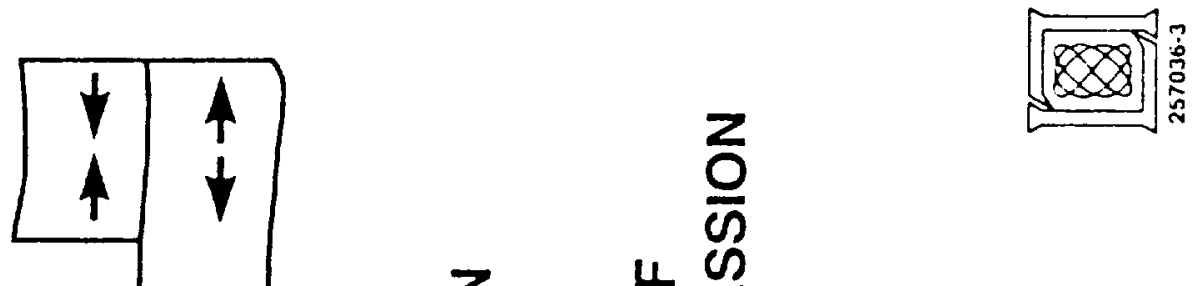

岂

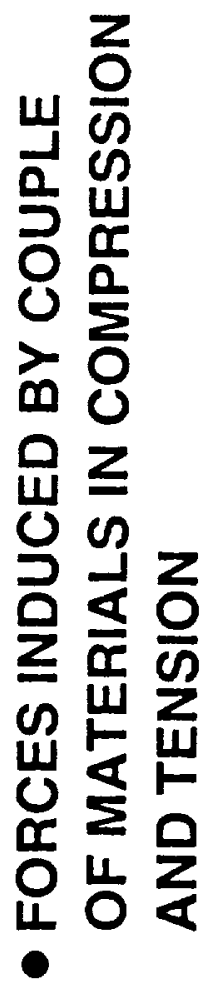




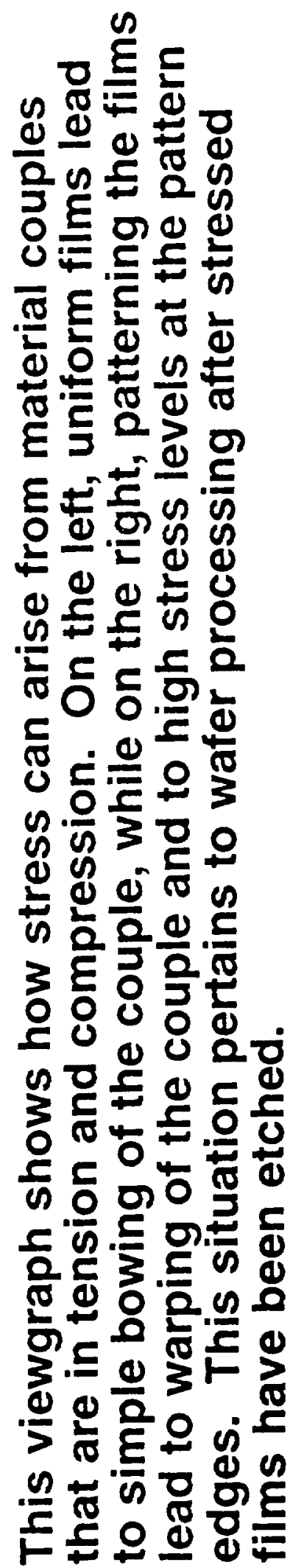




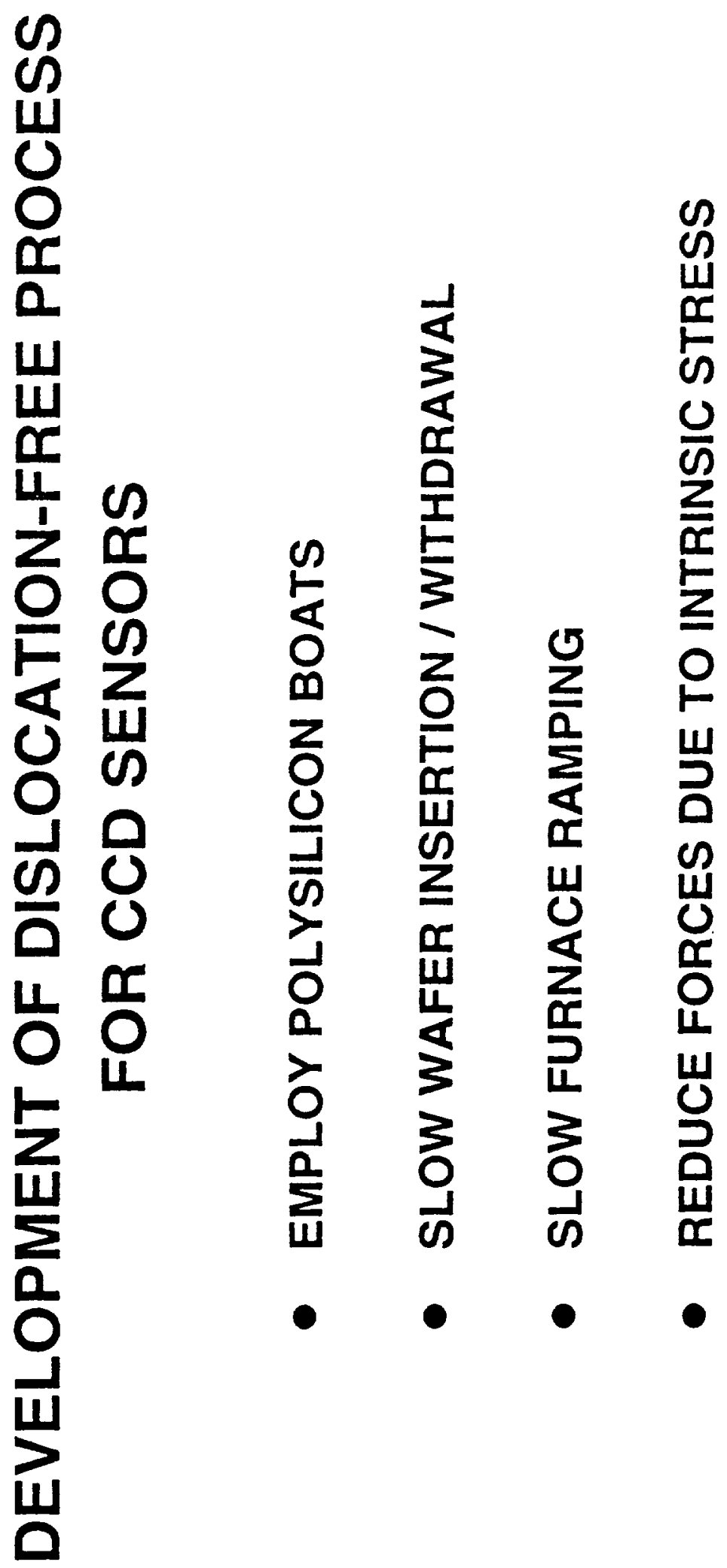

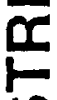

0

$z$

0

U

S

U1

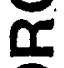

9

III 


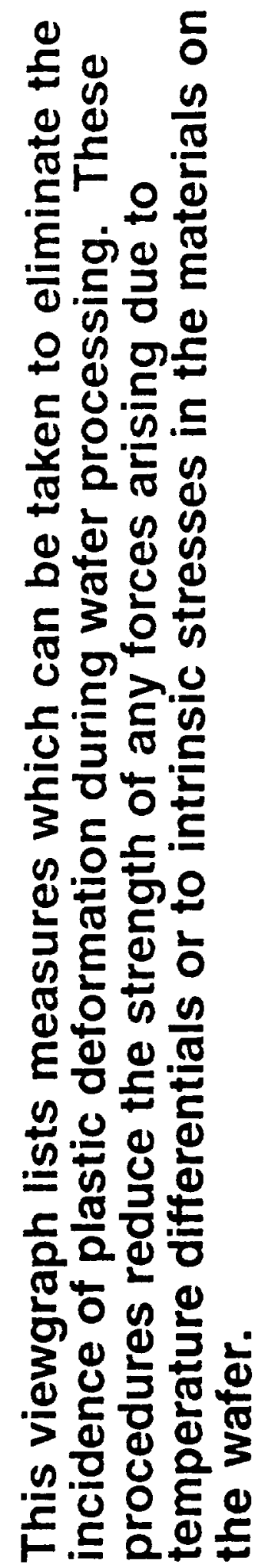


$\frac{w}{3}$

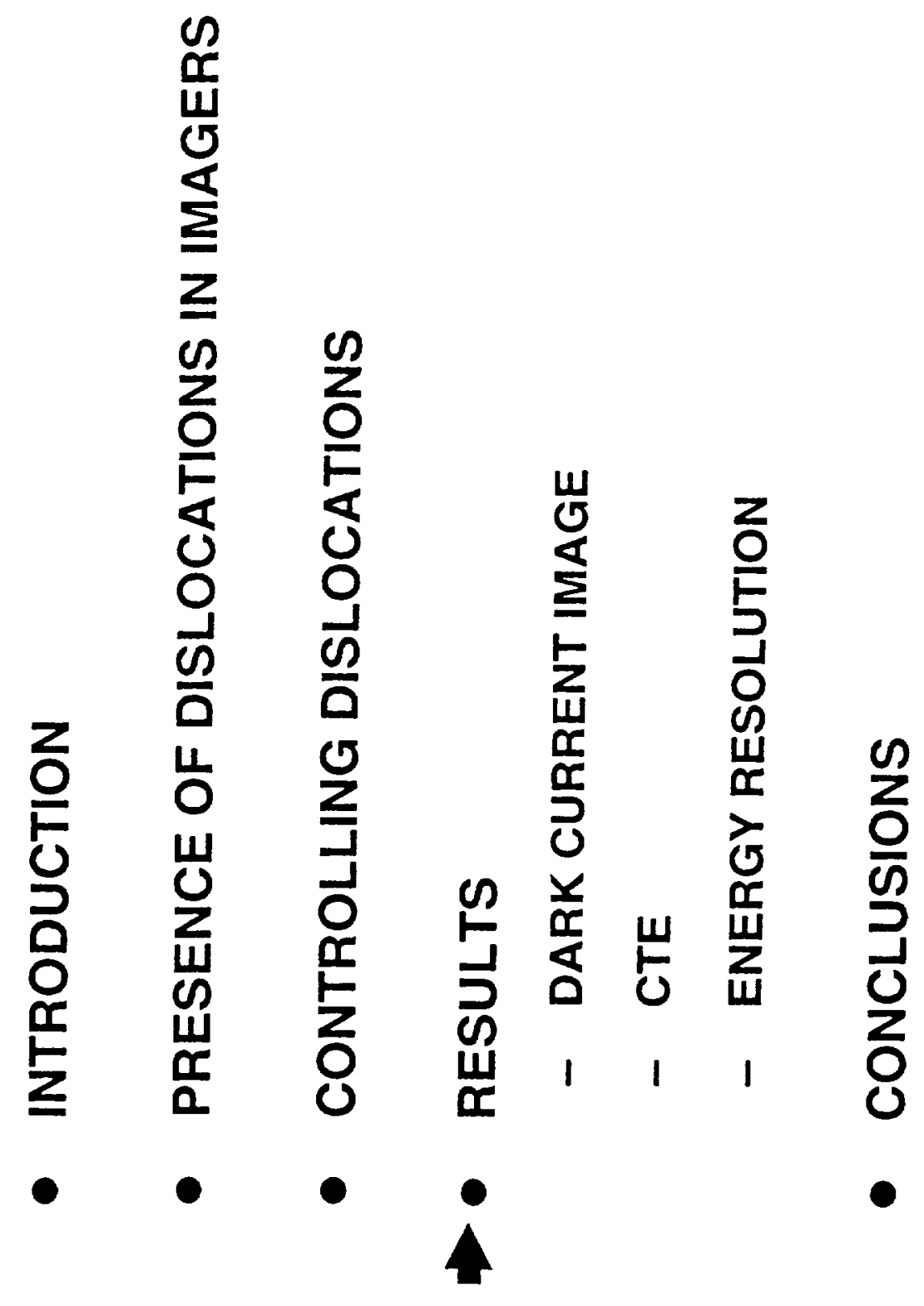




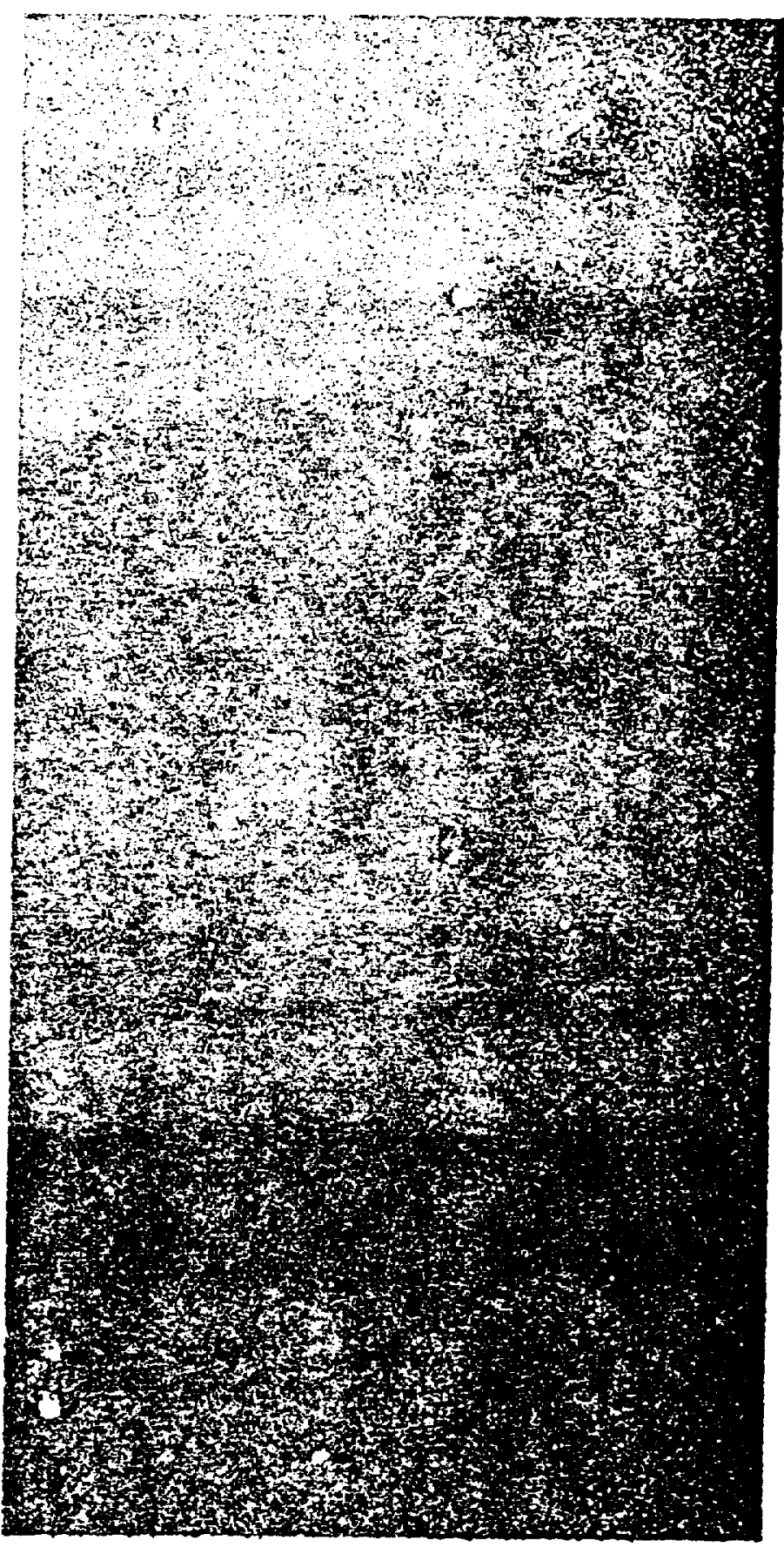




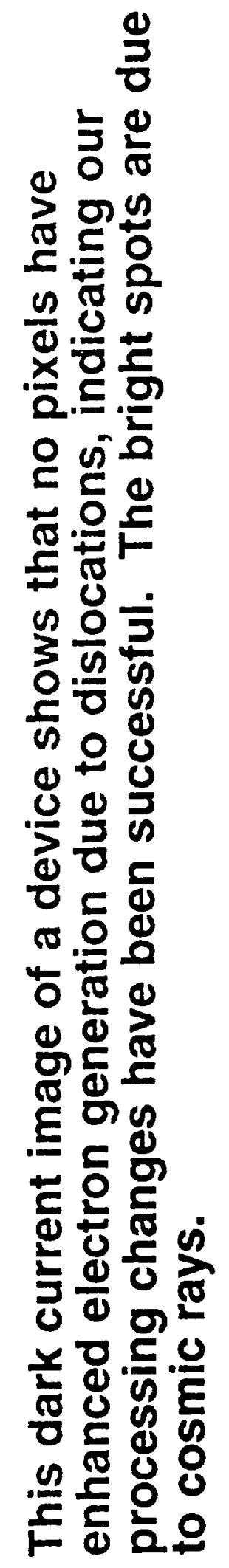




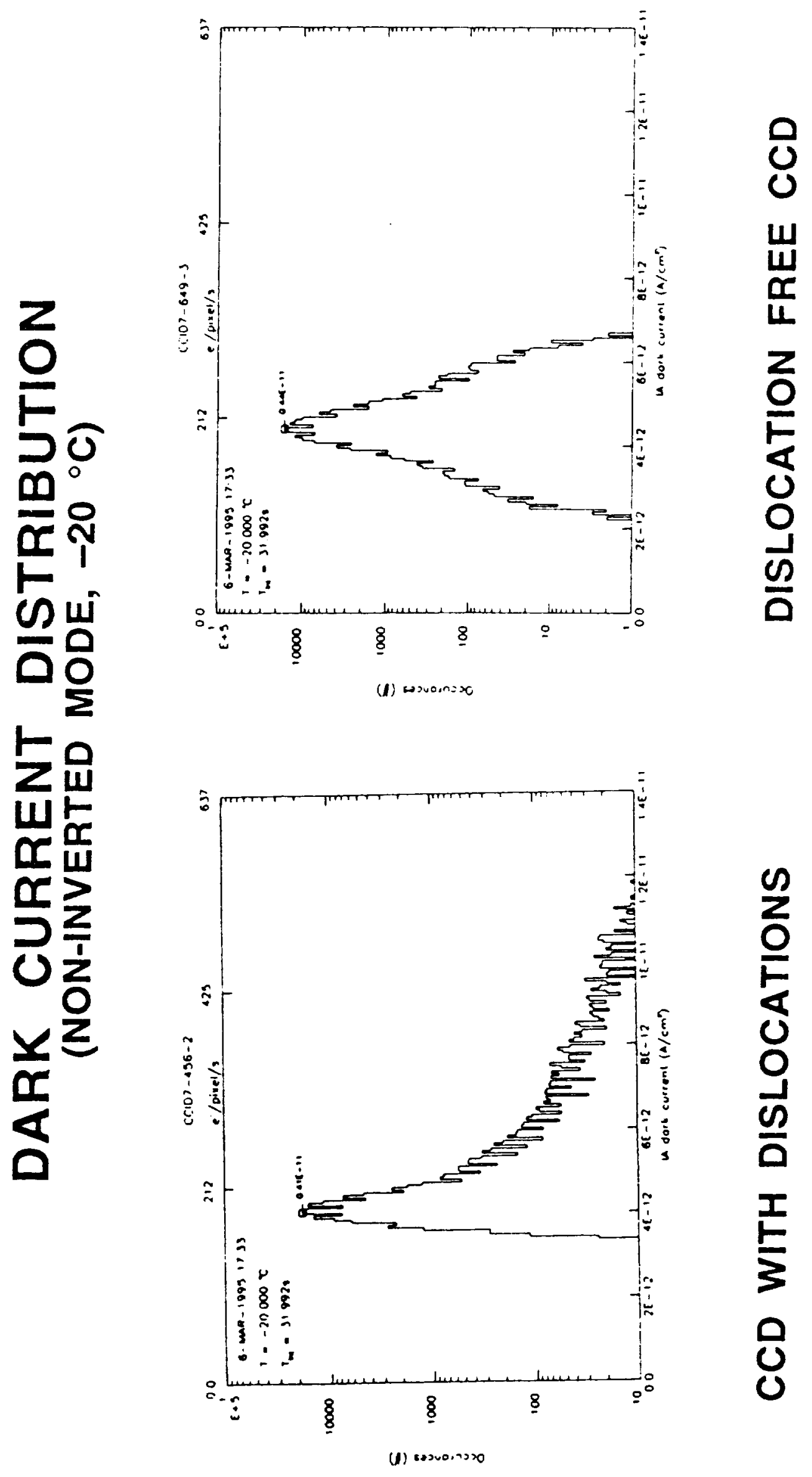




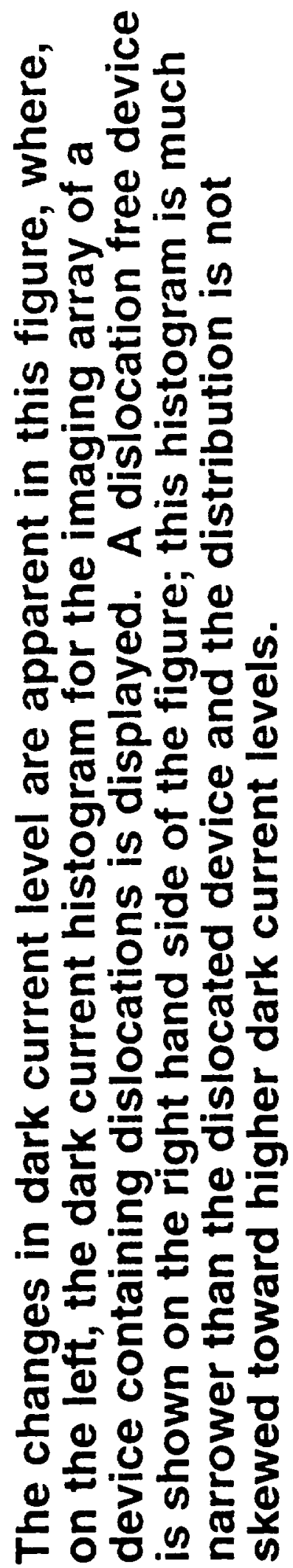



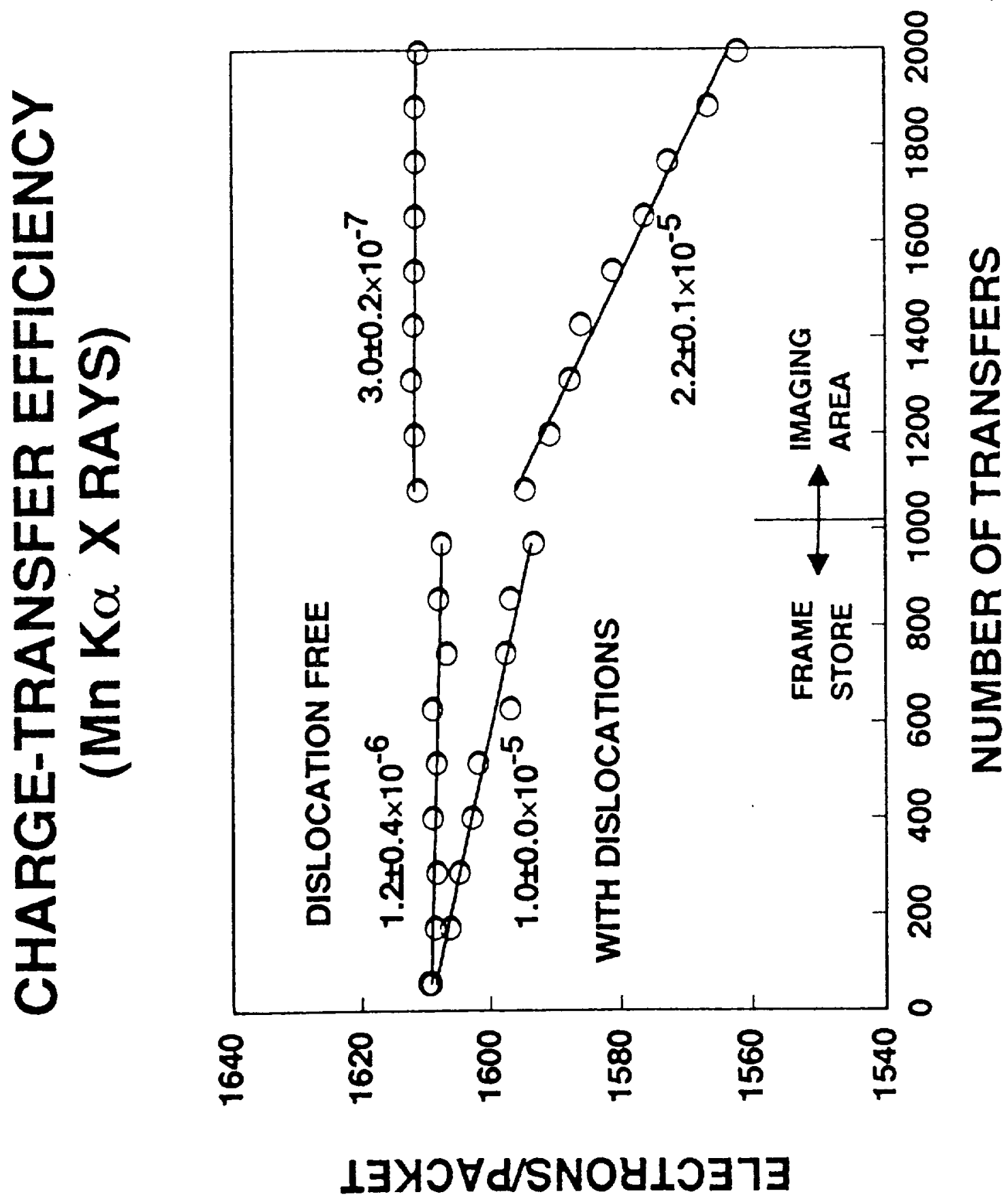


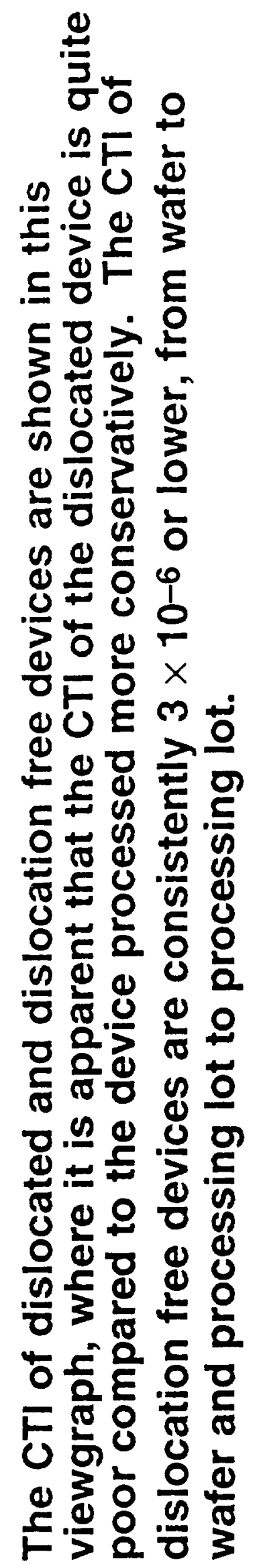


c

D

工㟧

E

$3 z$

z응

응 엉

5 क

$3 \frac{1}{0}$

O

$\infty$

山

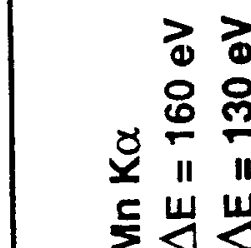

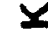

오ำ

II

r

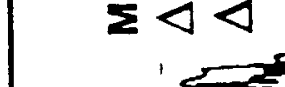

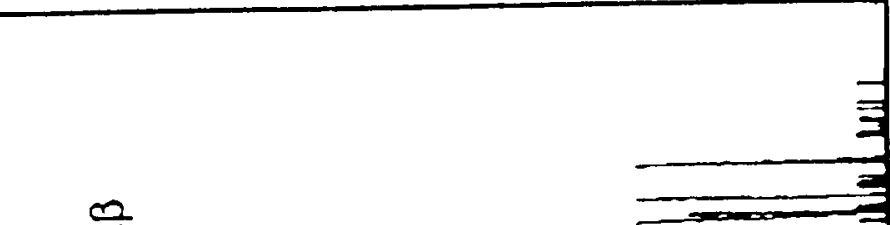

$\Longrightarrow$

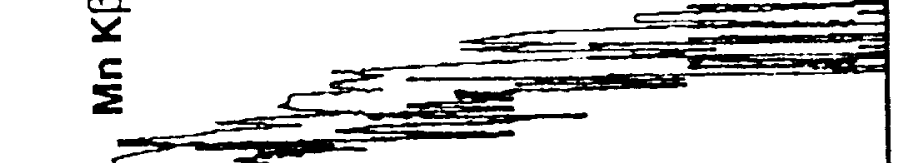

8

8

8
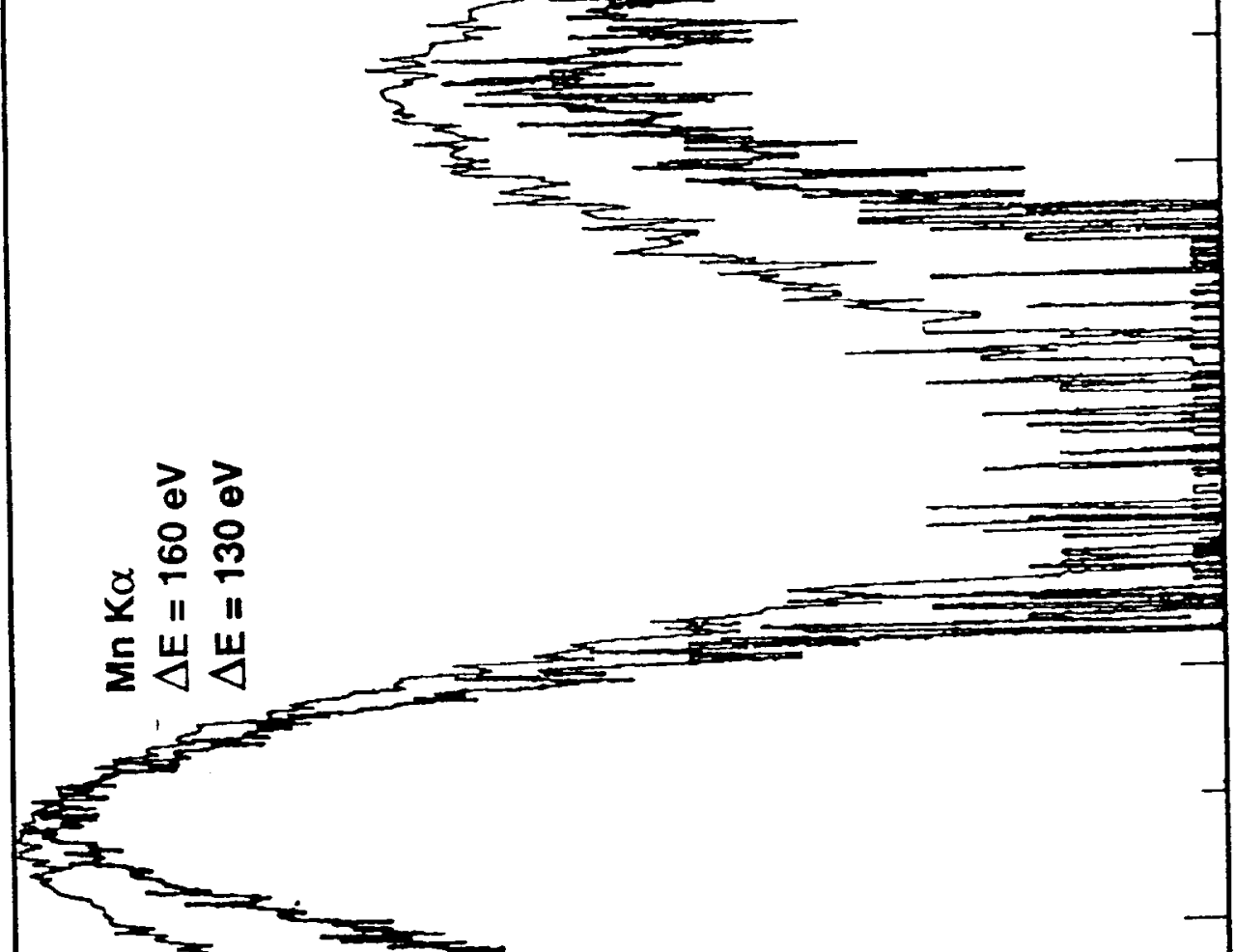

8

옹

8

8

它

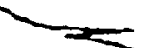

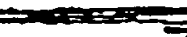
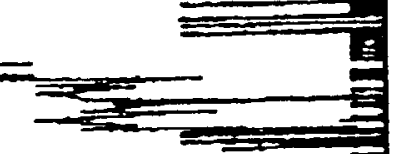

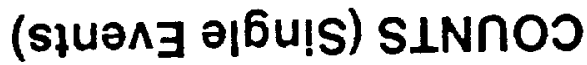




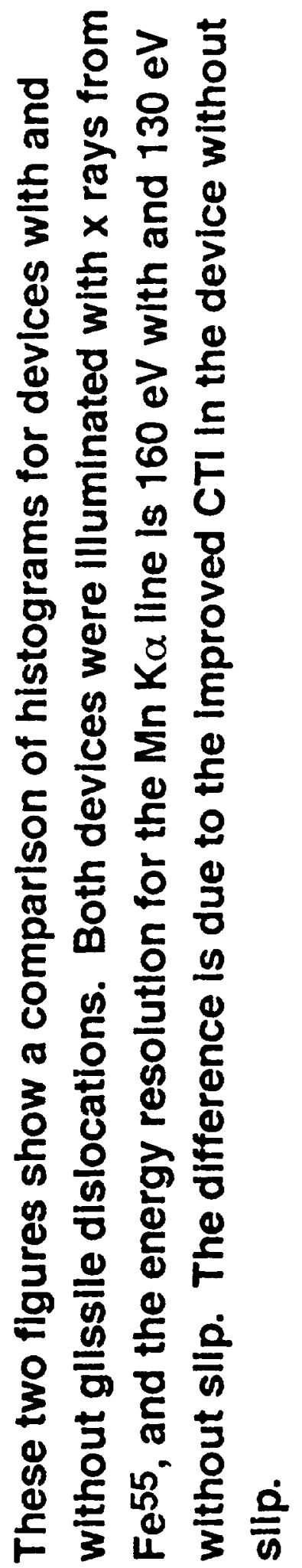




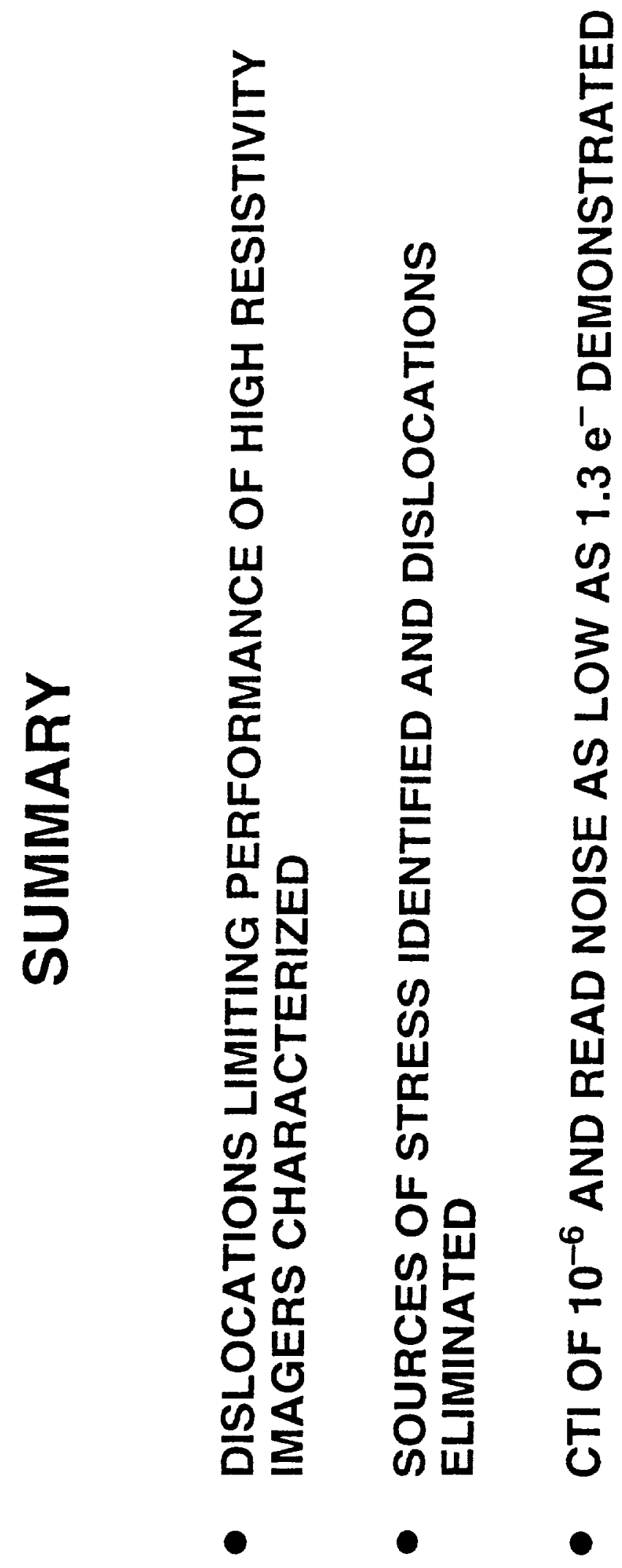

